Introduction: For people suffering from cancer the psychological problems are equally severe as those of somatic nature. This type of illness dramatically affects the basis of their existence and their value system. In order to return to a psychological balance it is vital to have support from people around them and to accept the illness at least at a level at which the patient is motivated for treatment.

The aim of this study was to determine whether people suffering from lung cancer are more affected by their value crisis, what the level of their acceptance of the illness is, and what type of public support they receive in comparison to people suffering from other lung diseases.

Material and methods: The study was conducted on 50 individuals ( 28 women, 22 men), of whom 25 had lung cancer and 25 suffered from a different lung disease (in both groups there were 14 women and 11 men). In the study the following instruments were used: Questionnaire to Investigate the Crisis of Value System (KKW), Acceptance of Illness Scale (AIS) and Scale of Social Support (SWS). The study was conducted between February and March 2010 at the pulmonological ward of a hospital.

Results: The results of the study show that people suffering from lung cancer have a more severe value crisis and accept their illness at a lower level compared to controls. Nevertheless, the study did not confirm the thesis that people suffering from lung cancer receive more valuing and emotional support than those with other lung diseases.

Key words: values, value system crisis, social support, acceptance of illness, lung cancer.

\section{Valuing crisis, acceptance of illness and social support among persons suffering from lung cancer}

\author{
Dorota Mącik, Sylwia Fijałkowska, Katarzyna Nycz
}

Faculty of Psychology, University of Finance and Management in Warsaw, Poland

\section{Introduction}

Lung cancer is the most common of the malignant tumours. It also shows the highest death rate compared to other tumours [1]. There are 20,000 people in Poland who suffer from this disease. Every year over 19,000 people die of lung cancer [1].

The functioning of patients with lung cancer is loaded with a number of difficulties connected with the illness, such as deep and tiring cough, and difficulties with breathing, especially during activities. It is important for the patient to have their family and friends close to them so they can calm down. They are nervous about their health and having the loved ones nearby is a vital factor [2]. Social acceptance is one of the essential elements of dealing with the illness, because the patient feels mental discomfort and anxiety connected with the loss of belief in treatment success [2], which in turn destabilizes the patient's value system.

The term "value" was established at the end of the 19th century and initially meant strength, health, courage and a strong character [3]. From the psychological point of view, values are the assurance for a human being of what is good and evil, desired and undesired, and what is the purpose of their activities [4]. Its hierarchy and relationships have an influence on an individual's mental health [5].

The valuing process is a derivative of a value system that an individual has [6]. It involves a particular moment in time but always in the context of future, present or past [7]. Thanks to it they can observe changes occurring in valuing that are influenced by different life occurrences.

The concept of valuing crisis is based on conclusions of humanistic psychology [8, 9]. It means disturbances and difficulties in the valuing process, of which the main characteristics are tension, anxiety and mental disintegration. It is accompanied by:

- a difficulty in ordering values into a hierarchy - an individual cannot determine one main value in their system, which consequently leads to a conflict between main values;

- re-evaluation - discovering new values as well as abandoning important, central beliefs and recognized values;

- lack of integration of cognitive, affective and motivational processes in valuing - an individual claims to have certain values, but simultaneously reacts emotionally negatively to them or evinces a low motivation for their implementation. Another extreme is a situation when an individual spends a large amount of time and energy on something unimportant or is highly motivated to do something which contradicts their value system;

- a feeling of not achieving values - understanding the discrepancies between accepted values and one's actions [6, 8].

Social support is a significant element in dealing with an illness. It consists of help received from friends and family, people significant to an individual and 
various institutions [10]. Support helps people with fulfilling their needs (mainly, a sense of affiliation, acceptance and safety). A key assumption is co-creating connections and relationships with others, which is acquired in the socializing process [11]. Such support embraces not only difficult situations but also continuous relations beneficial to good health and adaptation. It has a role in prevention, and is a potentially existing resource that can prevent stressors appearing [12].

According to the social exchange theory, social support can be understood as social interaction in which there is a mutual exchange of emotions, information, means of actions, and goods. Its aim is to minimize stress and to help in crises by presenting a sense of security, companionship, building a sense of affiliation and helping in finding solutions to a problem [11].

Natural systems (family, marriage) constitute the largest potential possibilities of providing support in a difficult situation (e.g. illness) [13, 14]. Marriage support plays a particularly important role. It is more effective due to the knowledge about a partner, understanding their needs, interaction frequency, affection, and doing each other favours. A spouse is seen as a basic and main source of support [15]. Research shows that people suffering from cancer and rating their partner's support highly experience less stress due to the illness [16].

Basic types of support are the following: emotional, cognitive (information exchange allowing better understanding of the situation), instrumental (specific methods of behaviour, effective remedial behaviour shaping), tangible (financial support, etc.) and spiritual (help during an existential crisis and in terminal situations) [11, 17].

Summing up [10,18], social support can be defined as an action, the social interaction of people or social groups towards others. It is initiated by either one or both sides, and can be intentional or unintentional, intended or unintended, professional (special support group) or unprofessional (society). It involves individuals or social groups in a critical situation. It is manifested through the exchange of information, services, goods, feelings, and social affinity. The scale of the psychological aspect is vital both in the process of interpreting the need for support and in the nature of supporting actions. They are voluntary in the giving aspect as well as when receiving them. What is important, group or individual support is not responsible for those supported, who preserve their autonomy. It is connected with the involved symmetry between supported and supporting, with no significant advantage to either side [10].

However, not every type of support is perceived positively by a patient. Research shows that support from friends can help with adaptation to an illness, whereas family support may have no meaning at all [19]. Patients seek emotional support from their families whilst from their doctors and other patients they need informational support. The interaction between patient and doctor is said to be the most helpful [20]. Social support (especially structural and institutional) is one of the factors partly connected with the inhibition of cancer development [21]; therefore, support providing reliable information about an illness helps to solve problems, deal with reactions to the illness, reduce negative emotions and causes higher self-esteem, which means patients adjust to the situation better [22, 23].
Somatic illness also influences the mental functioning of an individual. That is why it is important how the mental process of adjusting, acceptance and adaptation to the illness unfolds. It relies on restoring the patient's mental balance, lessening emotional discomfort and obtaining a relatively good state of mind [24].

One of the factors conditioning adjusting to the illness is believing in one's own and the doctor's influence on the illness development [22]. The illness stage, patient's age, selfassessment and self-image are among the factors linked to illness acceptance $[25,26]$.

Illness acceptance and adjustment can be examined by various aspects: emotional and cognitive adaptation, and interactions with others [27]. When the illness is long-lasting and proceeds slowly, accustomisation is an effective adaptation mechanism. An ill person slowly acclimatizes to a situation, accepts the limitations and discomforts as a new element of life [24].

\section{Material and methods}

The aim of the study was to answer the following question: What is the degree of value crisis and illness acceptance among people suffering from lung cancer and what type of support do they receive from their family and friends in comparison to those suffering from other lung diseases?

The assumptions were as follows:

- people suffering from a lung cancer experience a stronger value crisis than those suffering from other types of lung diseases;

- people suffering from a lung cancer receive higher valuing and emotional support than those suffering from other types of lung diseases;

- people suffering from a lung cancer accept their illness to a smaller extent than those suffering from other types of lung diseases.

In the studies the following methods were used: Questionnaire to Investigate the Crisis of Value System (KKW), Scale of Social Support (SWS) and Acceptance of Illness Scale (AIS).

The structure of KKW was created on the basis of the description of value crisis and the distinction of its symptoms according to various valuing aspects [6]. It is used in research on difficulties and disorders in the value system among mentally healthy people. It consists of 25 items (24 diagnostic items). There is an overall result and one in four sub-scales used to study the main symptoms of value crisis:

- $\mathrm{H}$ - a difficulty in ordering values into a hierarchy,

- Z - value insecurity,

- D - value disintegration,

- $\mathrm{R}$ - sense of unfulfilled values.

High scores denote a value crisis, that is, difficulties or disorders in a value system.

The Scale of Social Support (SWS) is based on Tardy's support concept [28, 29], which distinguishes four types of support (which were used in constructing the scale) [28]:

1) emotional,

2) valuing,

3) instrumental,

4) informative. 
The Scale of Social Support helps to acquire an overall level of social support without the division into types (maximum of 1440 points, denoting no support at all; minimum of 72 points, denoting high social support) and results referring to the different types of support [28].

The Acceptance of Illness Scale in the Polish adaptation by Juczynski [31] consists of eight statements describing consequences resulting from bad health, which lead to limitations imposed by an illness, no self-sufficiency, a sense of dependence on others and lowered self-esteem.

The measure of the level of acceptance is the amount of points, ranging from 8 to 40 . A low score means a lack of acceptance and adaptation and a sense of mental discomfort, while a high score means accepting the illness and lack of any negative emotions connected with it.

The study was conducted with the patients' and the hospital chiefs' agreements on 50 patients of the pulmonological ward at the Specialist Hospital in Sanok, Poland (25 patients with lung cancer and 25 patients with lung cancer in terminal stage of disease). In each group there were 14 women and 11 men. Both in the whole group and in particular groups the age ranged from 45 to 60 (the whole trial: $M=52, S D=4.31$, the lung cancer group: $M=53, S D=3.88$, the group with other lung diseases: $M=51.80, S D=4.71$ ).

The study was conducted in accordance with the Declaration of Helsinki (1975, regarding ethical principles not al- lowing providing patients' names, initials or hospital record number).

\section{Results}

The results of the study show that among those suffering from lung cancer compared to those suffering from other lung diseases there is indeed a stronger value crisis in all aspects involving valuing included in KKW: difficulties in ordering values in a hierarchy (scale H), value insecurity (scale Z), value disintegration (scale D), and a sense of unfulfilled values (scale R). The results are presented in Table 1.

The results of the study show that those suffering from lung cancer receive less general social support as well as valuing, informative and instrumental support compared to those suffering from other lung diseases. However, they receive the same amount of emotional support, which contradicts the theory stated (see Table 2).

Based on the results it was also found that those suffering from lung cancer accept their disease significantly less than those suffering from other lung diseases (see Table 3).

\section{Discussion}

The results of the study reveal vital differences in the value crisis, acceptance of illness and partially in the range of social support between patients suffering from lung cancer and those suffering from other lung diseases.

Table 1. Comparison of valuing crisis between groups with lung cancer and other lung disease

\begin{tabular}{|lcccccc}
\hline Scores in KKW test & \multicolumn{2}{c}{ Lung cancer $(N=25)$} & \multicolumn{2}{c}{ Other lung disease $(N=25)$} & \multicolumn{2}{c}{ Mann-Whitney U-test } \\
\cline { 2 - 7 } & Average rank & Sum of ranks & Average rank & Sum of ranks & $Z$ & $p$ \\
\hline General score & 33.42 & 835.5 & 17.58 & 439.5 & -3.92 & 0.000 \\
\hline H- difficulty in ordering & 34.44 & 861.0 & 16.56 & 414.0 & -4.38 & 0.000 \\
\hline Z-value insecurity & 31.46 & 786.5 & 19.54 & 488.5 & -3.04 & 0.001 \\
\hline D - value disintegration & 32.00 & 800.0 & 19.00 & 475.0 & -3.40 & 0.000 \\
\hline R- sense of unfulfilled values & 31.98 & 799.5 & 19.02 & 475.5 & -3.24 & 0.000 \\
\hline
\end{tabular}

Table 2. Comparison of perceived need of social support between groups with lung cancer and other lung disease

\begin{tabular}{lcccccc}
\hline Scores in SWS test & \multicolumn{2}{c}{ Lung cancer $(N=25)$} & \multicolumn{2}{c}{ Other lung disease $(N=25)$} & \multicolumn{2}{c}{ Mann-Whitney U-test } \\
\cline { 2 - 5 } & Average rank & Sum of ranks & Average rank & Sum of ranks & $Z$ & $p$ \\
\hline General score & 31.68 & 792.0 & 19.32 & 483.0 & -3.00 & 0.001 \\
\hline Informative support & 30.48 & 762.0 & 20.52 & 513.0 & -2.44 & 0.007 \\
\hline Instrumental support & 30.04 & 751.0 & 20.96 & 524.0 & -2.21 & 0.013 \\
\hline Valuing support & 31.26 & 781.5 & 19.74 & 493.5 & -2.81 & 0.002 \\
\hline Emotional support & 27.74 & 693.5 & 23.26 & 581.5 & -1.11 & 0.134
\end{tabular}

Table 3. The level of acceptance of illness - comparison between groups with lung cancer and other lung disease

\begin{tabular}{lccccc} 
Scores in AIS test & \multicolumn{2}{c}{ Lung cancer $(N=25)$} & \multicolumn{2}{c}{ Other lung disease $(N=25)$} & Mann-Whitney U-test \\
\cline { 2 - 5 } & Average rank & Sum of ranks & Average rank & Sum of ranks & $Z$ \\
Acceptance of Illness & 20.26 & 506.5 & 30.74 & 768.5 & -2.55
\end{tabular}


The patients with lung cancer experience disorders or difficulties with the valuing process on a larger scale compared to the control group.

People with cancer frequently have raised levels of depression and anxiety [32-34], which makes it difficult to direct life towards one's aspirations and their realization. Values create the system. Facing a choice, an individual chooses values from the top of the hierarchy [35]. When an individual is terminally ill, this value system is shaken. The hierarchy of the sick is unstructured, which leads to doubts and conflicts. This leads to experiencing a feeling of insecurity and rejecting values that were highly esteemed and fulfilled. With time these people lose motivation, and become inconsistent with their life goals chosen on the basis of the previously built value system. Being aware of the illness and its consequences has a negative influence on the earlier established value hierarchy; it becomes disorganized and shaken, and thus people with lung cancer experience a value crisis. The results show that these patients have difficulties with ordering their value system into a hierarchy, which mainly leads to doubts about values in life and what comprises the most important value in their life.

The study shows that there is a sense of loss of values and a rejection of the values recognized previously - values that were standard in their life and were contributing to achieving some of their goals or actions. It is possible to relate to a certain degree to the disagreement between an ideal hierarchy, which shows what a person wants to be like, and an actual hierarchy, which shows what a person is really like [35]. This discord grows rapidly among those suffering from lung cancer.

Patients with lung cancer frequently have disorganized values, which is characterized by a low motivation to achieve any values and goals, a low perseverance and a conflict between values that are recognized as perceptible. They lack a feeling of satisfaction from their value system, but factors connected with their disease do not allow them to change or return to a previously ordered hierarchy. After the diagnosis, all of their values become partly or completely re-evaluated and what was until this moment obvious and ordered is now changed.

Despite struggles with the symptoms or effects of diseases in the control group, patients do not face the idea that their disease may be terminal. Therefore, although their value system can undergo a change, it is not on the same scale and intensity as that of patients with lung cancer.

A far as social support is concerned, the studies did not prove the theory. People with lung cancer receive less social support than people from the control group. There are significant differences in informative, instrumental and valuing support, but almost no distinction in emotional support.

The reason for such results may be the type of disease. Patients with cancer face such a difficult problem that they feel they were left alone with it and it became a sentence for them. They experience a crisis and even though their family and friends are trying to support them, they do not notice it or feel it is not enough. Perhaps these people need a different type of support or prefer to stay independent, which may lead to avoiding others' support.
The results show that patients with cancer feel they receive less valuing support, which is connected with confirmation from friends and family that they are someone important to them. Another type of support that is missing among patients with cancer is instrumental support, which is connected with providing various goods and services. The last type of support that is not received by the patients is informative support, which means receiving advice to solve their problem. This could help them understand their situation better. Structural support would be helpful as an element of local and medical communities [36].

Patients with cancer face a disease which shifts their position in society, which consequently leads to various interactional disorders. Perhaps they cannot accept help offered to them. A patient needs support in different areas both from family and friends as well as other sources.

However, with an illness such as cancer it is not only the patient who needs support but also their family and medical staff [10]. Study reports show that in some cases patients' spouses experience greater overall stress, depression and anxiety and lower support from their own families than the patients themselves. Perhaps this may be a reason why spouses' help is less effective.

Results of the study also prove that patients with cancer accept their disease to a lesser extent compared to those suffering from other lung diseases. People with cancer may experience a strong mental discomfort and negative feelings connected with the disease, which may lead to lowered efficiency due to illness progression. It seems that those patients' fitness is more highly affected as a result of the illness itself and the long-lasting treatment $[1,38,39]$. It is possible that there is no sense of self-sufficiency but that there is a feeling of dependence from others, and lowered self-esteem, which as a result has an effect on adaptation and acceptance of the illness.

Perceiving illness as an alternative state to a healthy life, which everyone experiences sooner or later, can be a factor that has a positive influence on accepting the illness [40]. Tangible social support from doctors and nurses [22], and especially from friends and family, is highly helpful. These factors may lead to a better stabilization of the acceptance of the illness so that the patient has strength to fight as well as for further treatment.

\section{Thanks}

The authors of this text wish to thank the management of the pulmonological ward at the Specialist Hospital in Sanok, Poland for collecting data.

\section{References}

1. Daniluk J, Jurkowska G. Zarys chorób wewnętrznych dla studentów pielegniarstwa. Wydawnictwo Czelej, Lublin 2005.

2. Koper A, Wrońska I. Problemy pielęgnacyjne pacjentów z chorobą nowotworowa. Wydawnictwo Czelej, Lublin 2003.

3. Talarczyk M. Wychowanie do wartości. Znaczenie wartości. Wychowawca 2004; 6: 8-10.

4. Martynowicz E. Motywy, cele, wartości. Przyczynek do zrozumienia stanu ducha i stanu umysłu współczesnych Polaków. Oficyna Wydawnicza „Impuls”, Kraków 2004. 
5. Kościuch J. Hierarchie wartości w nerwicach i psychopatii oraz ich zmiany pod wpływem psychoterapii. Akademia Teologii Katolickiej, Warszawa 1984.

6. Oleś P. Kwestionariusz do Badania Kryzysu w Wartościowaniu. Podręcznik. Pracownia Testów Psychologicznych, Warszawa 1998.

7. Hermans HJM, Oleś P. The personal meaning of values: Continuity - discontinuity of value experience. Polish Psychological Bulletin 1996; 4: 301-17.

8. Oleś P. Wartościowanie a osobowość: Psychologiczne badania empiryczne. Redakcja Wydawnictw KUL, Lublin 1989.

9. Hermans HJ, Oleś P. Value crisis: Affective organization of personal meanings. Journal of Research in Personality 1996; 30: 457-82.

10. Kwaśniewska G, Wojnarska A. Aktualne problemy wsparcia społecznego osób niepełnosprawnych. Wydawnictwo Uniwersytetu Marii Curie-Skłodowskiej, Lublin 2004.

11. Sęk H. Wsparcie społeczne jako kategoria zasobów i wieloznaczne funkcje wsparcia. W: Zasoby osobiste i społeczne sprzyjające zdrowiu jednostki. Ogińska-Bulik N, Juczyński Z (red.). Wydawnictwo Uniwersytetu Łódzkiego, Łódź 2003; 17-32.

12. Sęk H, Cieślak R. Wsparcie społeczne, stres i zdrowie. Wydawnictwo Naukowe PWN, Warszawa 2004.

13. Snyder KA, Pearse W. Crisis, social support, and the family response: Exploring the narratives of young breast cancer survivors. J Psychosoc Oncol 2010; 4: 413-31.

14. Talley A, Molix L, Schlegel RJ, Bettencourt A. The influence of breast cancer survivors' perceived partner social support and need satis faction on depressive symptoms: A longitudinal analysis. Psychol Health 2010; 4: 433-49.

15. Popiołek K. Psychologia bliżej życia - Chowanna. Cz. I. Wydawnictwo Uniwersytetu Ślaskiego, Katowice 2005; 2: 118-28.

16. Rini C, Redd WH, Austin J, et al. Effectiveness of partner social sup port predicts enduring psychological distress after hematopoietic stem cell transplantation. J Consult Clin Psychol 2011; 1; 64-74.

17. Cieślak R. Wsparcie społeczne a stres w pracy kierowniczej. Czasopismo Psychologiczne 1998; 4: 29-46.

18. Winiarski M. Od opieki do wsparcia społecznego. Problemy Opiekuńczo-Wychowawcze 1999; 5: 3-8.

19. Cicero V, Lo Coco G, Gullo S, Lo Verso G. The role of attachment di mensions and perceived social support in predicting adjustment to cancer. Psychooncology 2009; 10: 1045-52.

20. Mehnert A, Lehmann C, Graefen M, Huland H, Koch U. Depression, anxiety, post-traumatic stress disorder and health-related quality of life and its association with social support in ambulatory prostate cancer patients. Eur J Cancer Care 2010; 6: 736-45.

21. Nausheen B, Gidron Y, Peveler R, Moss-Morris R. Social support and cancer progression: A systematic review. J Psychosom Res 2009; 5: 403-15.

22. Skrzyński W. Psychologiczne wyznaczniki jakości życia osób przewlekle chorych. Wydawnictwo Naukowe Medium, Warszawa 2006.

23. Schroevers MJ, Helgeson VS, Sandernnan R, et al. Type of social support matters for prediction of posttraumatic growth among cancer survivors. Psycho-Oncology 2010; 1: 46-53.

24. Zasady diagnostyki i leczenia bólu. Podstawy opieki paliatywnej. Jarosz J, Hilgier M, de Walden-Gałuszko K. (red). Wydawnictwo Lekarskie PZWL, Warszawa 2006.

25. Spanea E, Kalantzi-Azizi A, Skarlos D. Psychosocial factors and adjustment to breast cancer: A structural equation model. Hellenic Journal of Psychology 2005; 2: 182.

26. Wrona-Polańska H. Self-concept and adjustment to illness in leukemia patients. Polish Psychological Bulletin 1991; 3: 169-78.

27. Bishop GD. Psychologia zdrowia. Zintegrowany umysł i ciało. Wydawnictwo ASTRUM, Wrocław 2000.

28. Kmiecik-Baran K. Skala Wsparcia Społecznego. Teoria i wartości psychometryczne. Przegl Psychol 1995; 1/2: 201-14.

29. Tardy ChH. Social Support measurement. Am J Comm Psychol 1985; 2: 187-202.

30. Felton BJ, Revenson TA, Hinrichsen GA. Stress and coping in the explanation of psychological adjustment among chronically ill adults. Soc Sci Med 1984; 10: 889-98.

31. Juczyński Z. Narzędzia Pomiaru w Promocji i Psychologii Zdrowia. Pracownia Testów Psychologicznych PTP, Warszawa 2001.
32. Schou I, Ekeberg ?, Sandvik L, Ruland CM. Stability in OptimismPessimism in Relation to Bad News: A Study of Women With Breast Cancer. J Pers Assess 2005; 2: 148-54.

33. Hinz A, Krauss O, Hauss JP, Höckel M, Kortmann RD, Stolzenburg JU, Schwarz R. Anxiety and depression in cancer patients compared with the general population. Eur J Cancer Care 2010; 4: 522-9.

34. Sharpley CF, Bitsika VC, David RH. Helping prostate cancer patients understand the causes of anxiety and depression: Comparing cancer-caused vs patient response events. Journal of Men's Health 2009; 4: 345-53.

35. Kępiński A. Lęk. PZWL, Warszawa 1987.

36. Caplan G. Support systems and community mental health. Behavioral Publications, New York 1974.

37. Hasson-Ohayon I, Goldzweig G, Braun M, Galinsky D. Women with advanced breast cancer and their spouses: Diversity of support and psychological distress. Psychooncology 2010; 11: 1195-204.

38. Papliński Z, Jassem J. Rak płuca. Wydawnictwo Lekarskie PZWL, Warszawa 1994.

39. Chazan R. Pneumonologia i alergologia praktyczna-wybrane jednostk chorobowe. Medica Press, Bielsko-Biała 2002.

40. Zamiara K. Kulturowy wymiar kategorii choroby. W: Zdrowie i choroba. Problemy teorii diagnozy i praktyki. Brzeziński JM, Cierpiałowska L (red.). Gdańskie Wydawnictwo Psychologiczne, Gdańsk 2008; 3-9.

\section{Address for correspondence}

\section{Dorota Mącik}

Wyższa Szkoła Finansów i Zarządzania

Wydział Psychologii

Pawia 55

01-030 Warszawa

tel. +48 2253654 21, +482253654 11

e-mail: dorota_macik@tlen.pl 